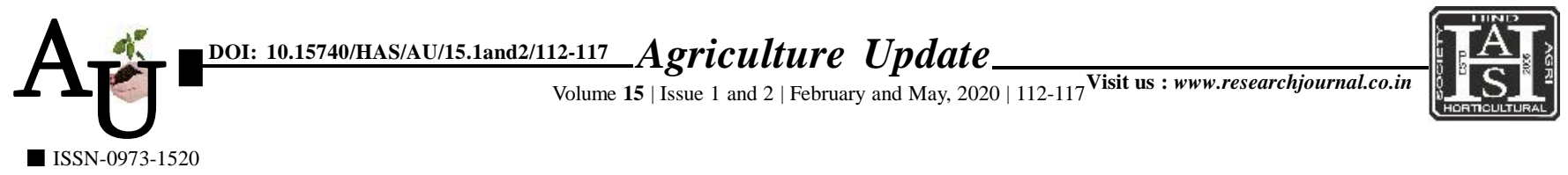

\title{
A Case Study : \\ Efficient utilization of water bodies increasing the cropping intensity of North Pulinpur ADC village of Tripura, India-Acase study under NICRA project
}

\author{
Dipankar Dey, Dipak Nath, Lord Litan Debbarma, Subhra Shil, Suresh Chandra \\ Biswas, Ardhendu Chakraborty, Rajib Das, Nurul Islam, Subrata Choudhury and \\ Prasanto Reang
}

Article Chronicle: Received : 09.07.2019;

Accepted : 25.04.2020

KEY Words : NICRA, KVK Khowai, Paddy

Author for correspondence :

\section{Dipankar Dey}

Krishi Vigyan Kendra, Khowai (Tripura) India

Email: ddey611@gmail.

com

See end of the article for authors' affiliations
SUMMARY : North Pulinpur with GPS location $23^{\circ} 52.836^{1} \mathrm{~N}, 91^{\circ} 35.275^{1} \mathrm{E}$ and elevation $47 \mathrm{~m}$ is one of the draught prone tribal inhabited ADC village of the district Khowai under the state Tripura. The total geographical area of the village is 950 hectare with cultivable area of about 250 hectare only among 806 farm families. So, most of the families are holding either small or marginal farms. There was no perennial streams, rivers, ponds and other irrigation facilities in the village. Prevailing temperature ranges from $16^{\circ} \mathrm{C}$ to $37^{\circ} \mathrm{C}$. Annual rainfall ranges from 2050 to $2550 \mathrm{~mm}$, but almost whole amount goes out to neighboring lower elevated village. Agriculture is the mainstay of the people, about 85 per cent of them engage in agriculture and its allied activities. Farmers earned their livelihood from rainfed rice based monocropped cultivation. Moisture stress during Kharif dry spell and winter season which lead to rice based mono-cropping system. Under the National Innovations in Climate Resilient Agriculture(NICRA) Project KVK,Khowai has constructed and rejuvenated 22 water bodies from 2011-12 to 2018-19 at North Pulinpur ADC village; all of which provided life saving irrigation for paddy during Kharif dry spell as well as during Rabi season through nano pumps installed nearby farm ponds. Before implementation of NICRA project to North Pulinpur ADC village, most of the areas remain dry during Rabi season. After the intervention, approximately $26187 \mathrm{ft}^{3}$ rainwater had been harvested covering an area of about 135.0 ha. for winter vegetables and Rabi maize cultivation and during dry period. In addition to this, a total area of about 1 ha waste land had been converted to paddy land using water from community bund. Ponds were also used for composite fish culture with average yield of 30 q/ farmer/year/ha during 2018-19.

How to cite this article : Dey, Dipankar, Nath, Dipak, Debbarma, Lord Litan, Shil, Subhra, Biswas, Suresh Chandra, Chakraborty, Ardhendu, Das, Rajib, Islam, Nurul, Choudhury, Subrata and Reang, Prasanto (2020). Efficient utilization of water bodies increasing the cropping intensity of North Pulinpur ADC village of Tripura, India - A case study under NICRA project. Agric. Update, 15(1 and 2): 112-117; DOI : 10.15740/HAS/AU/ 15.1and2/112-117. Copyright@2020: Hind Agri-Horticultural Society. 